Plant Production Science

http:/www.journals.zu.edu.eg/journalDisplay.aspx?Journalld=1\&queryType=Master

\title{
EFFECT OF CULTIVARS, AUXINS AND ACTIVATED CHARCOAL ON IN VITRO ROOTS FORMATION OF STRAWBERRY PLANTLETS
}

\author{
Heba-Allah M.M.A. Khalil $^{1 *}$, M.A.I. Khalil ${ }^{2}$, H.M.E. Arisha ${ }^{2}$ and M.E. El-Denary ${ }^{1}$ \\ 1. Potato and Veget. Propagated Veget. Dept., Hort. Res. Inst., Agric. Res. Cent., Giza, Egypt \\ 2. Hort. Dept., Fac. Agric., Zagazig Univ., Egypt
}

Received: 06/03/2019 ; Accepted: 15/04/2019

\begin{abstract}
This experiment amid to investigate the effect of two strawberry cultivars (Festival and Sweet Charlie), two auxins, i.e. Indole-3-butyric acid (IBA) and1-Naphthalene acetic acid (NAA) and activated charcoal on the in vitro roots formation (rooting stage) of strawberry plantlets. The obtained results showed that, Sweet Charlie cultivar being the superior one and recorded the maximum values of both root and shoot length, number of roots and leaves, the fresh and dry weight of roots and leaves of plantlet as compared with Festival cultivar. It is evident that, using $1 / 2$ MS-medium supplemented with $1.0 \mathrm{mg} / 1 \mathrm{IBA}+0.5 \mathrm{~g} / 1$ activated charcoal being the most effective and superior treatment for increasing both root and shoot length. While, rooting medium contained $1 / 2$ MS-medium $+1.0 \mathrm{mg} / 1 \mathrm{IBA}$ or $0.5 \mathrm{mg} / 1 \mathrm{IBA}+0.5 \mathrm{mg} / 1 \mathrm{NAA}$ recorded the highest values of number of both roots and leaves per plantlet .In addition, using $1 / 2$ MS-medium supplemented with $1.0 \mathrm{mg} / 1 \mathrm{NAA}$ recorded the maximum values of the fresh and dry weight of roots per plantlet. Furthermore, the highest value for each of fresh weight of crown and leaves per plantlet, was obtained by using $1 / 2$ MS-medium supplemented with $0.5 \mathrm{mg} / 1 \mathrm{IBA}+0.5 \mathrm{mg} / 1 \mathrm{NAA}$. On the other hand, using $1 / 2 \mathrm{MS}$-medium $+0.5 \mathrm{mg}$ $/ 1 \mathrm{IBA}+0.5 \mathrm{mg} / 1 \mathrm{NAA}+0.5 \mathrm{~g} / 1$ activated charcoal being the superior treatment and recorded the maximum values of nitrogen, phosphorus, potassium, total carbohydrate and total protein content (\%). Transfer shoots of Sweet Charlie cultivar to the rooting medium contained $1 / 2 \mathrm{MS}$ - medium $+1.0 \mathrm{mg} / 1$ IBA $+0.5 \mathrm{~g} / 1$ activated charcoal recorded the maximum values of both root and shoot length, number of leaves per plantlet, the fresh and dry weight of leaves, as well as the dry weight of crown per plantlet. While, the highest number of roots per plantlet was more achieve via using $1 / 2$ MS-medium + $1.0 \mathrm{mg} / 1$ IBA. Moreover, cultured shoots of Festival cultivar on $1 / 2$ MS-medium supplemented with 0.5 $\mathrm{mg} / 1 \mathrm{IBA}+0.5 \mathrm{mg} / 1 \mathrm{NAA}$ being the most effective and favorable treatment for increasing the fresh weight of roots per plantlet. On the other hand, the highest increase of the fresh weight of crown per plantlet were more distinct via the interaction treatment between such cultivar and using $1 / 2$ MSmedium supplemented with $1.0 \mathrm{mg} / 1 \mathrm{NAA}$. Furthermore, using the rooting culture medium contained $1 / 2$ MS- medium $+0.5 \mathrm{mg} / 1 \mathrm{IBA}+0.5 \mathrm{~g} / 1$ activated charcoal recorded the highest value for each of nitrogen and total protein content (\%) in the plantlets of Festival cultivar, while cultured shoots of Sweet Charlie cultivar on the same rooting medium, registered the maximum increase of phosphorus, potassium and total carbohydrates content (\%).
\end{abstract}

Key words: Strawberry, Indole-3-butyric acid ,1-Naphthalene acetic acid, activated charcoal, in vitro, roots formation

\section{INTRODUCTION}

Strawberry (Fragaria $X$ ananassa Duch.) belongs to family Rosaceae. It is a natural hybrid of Fragaria chiloensis Mill., and

\footnotetext{
* Corresponding author: Tel. : +201002143287

E-mail address: boba100100@yahoo.com
}

Fragaria virginiana Duch. The Strawberry fruits is delicated in flavor, texture ,shape, and rich in some vitamins particularly $\mathrm{A}, \mathrm{B}_{1}, \mathrm{~B}_{2}, \mathrm{~B}_{6}$, $\mathrm{C}, \mathrm{E}$ and some minerals such as calcium, potassium, copper and iron (Giampieri et al., 
2015). In addition, fruits are a good source of phylochemical compounds, mainly ellagic acid which have a wide range of biological activity. Strawberry is grown in many regions of Egypt mainly at Beheira, Ismailia, Sharkia and Qalyubia Governorates. The cultivated area of strawberry in Egypt were about 15614.4 faddans with production valued 283471 tons (FAO, 2014). This area of strawberry is in increasing over the years.

Tissue culture technique has been successful on the large scale multiplication of strawberry plants in many countries. This technique can produce several millions of plants in short time from a few mother plants. Beside propagation, tissue culture technique have been used for production of disease resistant plants, and in plant breeding and crop improvement programs (Mohamed, 2007).

Among the pathways for improvement the performance of strawberry plants in tissue cultures, cultivars (Ara et al., 2013; Murti and Yeoung, 2013), some auxins, such as IBA and NAA (Moradi et al., 2011; Badr-ELden, 2013; Harugade et al., 2014). as well as activated charcoal (Erenoglu et al., 1995; Adak et al., 2001; Kaushal et al., 2006; Adak et al., 2009) play a major role in this respect.

The main purposes of this work were to study the effect of two strawberry cultivars, two auxins (IBA and NAA) and activated charcoal on the roots formation of plantlets which cultured in vitro.

\section{MATERIALS AND METHODS}

This work was carried out during the period from 2012 to 2017 in the Tissue Culture Laboratory and Greenhouse of Improvement of the Main Vegetable Crops and Hybrids Production Project (I.M.V.C.H.P.), Horticulture Research Institute (HRI), Agriculture Research Center (ARC), Dokki, Giza Governorate, Egypt, to study the effect of two strawberry cultivars (Festival and Sweet Charlie),two auxins, i.e. Indole-3-butyric acid (IBA) and1-Naphthalene acetic acid (NAA) and activated charcoal on the in vitro roots formation.
This experiment included 12 treatments which were the combination between two strawberry cultivars and two auxins and activated charcoal treatments, as follows.

\section{Strawberry Cultivars}

1. Festival.

2. Sweet Charlie.

\section{Auxins and Activated Charcoal}

1. Half salts strength of MS ( $1 / 2$ MS-medium) + $1.0 \mathrm{mg} / \mathrm{l} \mathrm{IBA}$

2. $1 / 2 \mathrm{MS}$-medium $+1.0 \mathrm{mg} / \mathrm{l} \mathrm{NAA}$

3. $1 / 2 \mathrm{MS}-$ medium $+0.5 \mathrm{mg} / 1 \mathrm{IBA}+0.5 \mathrm{mg} / 1 \mathrm{NAA}$

4. $1 / 2$ MS-medium $+1 \mathrm{mg} / 1 \mathrm{IBA}+0.5 \mathrm{~g} / \mathrm{l}$ activated charcoal.

5. $1 / 2 \mathrm{MS}$-medium $+1 \mathrm{mg} / \mathrm{l} \mathrm{NAA}+0.5 \mathrm{~g} / \mathrm{l}$ activated charcoal.

6. $1 / 2$ MS-medium $+0.5 \mathrm{mg} / 1 \mathrm{NAA}+0.5 \mathrm{mg} / \mathrm{lBA}$ $+0.5 \mathrm{~g} / 1$ activated charcoal.

These treatments were arranged in split-plot design with six replicates. Each replicate contained two glass jars, and each one contained four explants. The strawberry cultivars were arranged in the main plots, while auxins and activated charcoal treatments were assigned randomly in the sub-plots.

Murashing and Skoog (1962) medium (MS) was used. All used shoots in this experiments were obtained from cultured meristems on half salt strength of basal MS-medium ( $1 / 2 \mathrm{MS}-$ medium) supplemented with the previouse auxins concentrations (IBA and NAA) and activated charcoal.

\section{Data Recorded}

Data were recorded after 6 weeks of culture in vitro, as follows:

\section{Growth Measurements of Plantlets}

1. Root length $(\mathrm{cm})$.

2. Shoot length $(\mathrm{cm})$.

3. Number of roots per plantlet.

4. Number of leaves per plantlet.

5. Fresh weight of roots per plantlet (g).

6. Fresh weight of crown per plantlet (g). 
7. Fresh weight of roots, crown and leaves/ plantlet were oven dried at $70^{\circ} \mathrm{C}$ till constant weight according to Dogras et al.(1991) and the following data were recorded:

8. Fresh weight of leaves per plantlet (g).

9. Dry weight of roots per plantlet $(\mathrm{g})$.

10. Dry weight of crown per plantlet (g).

11.Dry weight of leaves per plantlet (g).

\section{Chemical Composition of Plantlets}

Fresh samples of shoots per plantlets were oven dried at $70^{\circ} \mathrm{C}$ till constant weight according to Dogras et al. (1991). The dry matter of shoots was finely ground and wet digested with sulfuric acid and perchloric acid (3:1). The following data were determined and recorded:

Nitrogen (N) content (\%)

It was determined in shoot dry weight according to the methods described by Bremner and Mulvaney (1982).

\section{Phosphorus (P) content (\%)}

It was determined according to the methods described by Olsen and Sommers (1982).

Potassium (K) content (\%): was determined according to the methods described by Jackson (1970).

\section{Total carbohydrates content $(\%)$}

Was determined according to the methods described by James (1995).

\section{Total protein content $(\%)$}

Was calculated by multiplying total nitrogen $\mathrm{x} 6.25$, as described by Pregle (1945).

\section{Statistical Analysis}

All collected data were subjected to proper statistical analysis using Costat Soft Ware Program. The least significant difference (LSD) test at 0.05 level of probability was used to determine statistically the significance of differences among the compared means of various treatments according to Snedecor and Cochran (1980).

\section{RESULTS AND DISCUSSION}

\section{Growth Measurements of Plantlets}

\section{Effect of cultivars}

The presented results in Table 1 show the effect of strawberry cultivars, i.e. Festival and Sweet Charlie on the growth measurements of complete plantlets during rooting stage in vitro. In this regard, Sweet Charlie cultivar being the superior one for increasing length of both root and shoot, number of roots and leaves, fresh and dry weight of roots and leaves per plantlet as compared with Festival cultivar. On the other hand, it was quite clear from such results that, there are no obvious significant differences detected between the two cultivars in their fresh and dry weight of plantlet crown formation. In this connection, Ara et al. (2013) came to similar results on some strawberry genotypes. They concluded that, number of roots/shoots and frequency of roots induction ranged from 78 to $95 \%$ according to the genotypes. In addition, Murit and Yeoung (2013) reported that, Red Pearl strawberry cultivar recorded the highest root length as compared with Camarosa cultivar, the superior effect of Red Pearl cultivars, might be due to absorbed more water and reduced transpiration than Camarosa cultivar.

From the forgoing results and discussion, it could be suggested that, strawberry cultivars varied greatly from their response of roots formation per plantlet.

\section{Effect of auxins and activated charcoal}

As for the effect of the two auxins (IBA and NAA) and activated charcoal on in vitro strawberry plantlet development during rooting stage, the obtained results in Table 2 show that, all treatments had a significant effect on the growth measurements of plantlets, except the dry weight of plantlet crown which did not reflect any significant effect. Using Half salts strength MS-medium ( $1 / 2 \quad$ MS-medium) supplemented with $1 \mathrm{mg} / 1 \mathrm{IBA}+0.5 \mathrm{~g} / 1$ activated charcoal being the superior treatment in increasing root and shoot length of plantlet .In addition, using rooting medium contained $1 / 2$ MS-medium and supplemented with $1.0 \mathrm{mg} / 1$ IBA recorded the maximum increase in roots and leaves number per complete plantlet, followed by using rooting medium contained $1 / 2$ MS-medium supplemented with $0.5 \mathrm{mg} / 1 \mathrm{IBA}+$ $0.5 \mathrm{mg} / 1 \mathrm{NAA}$. 
Table 1. Effect of strawberry cultivars on the growth measurements of plantlets cultured in vitro at 6 weeks of culture

\begin{tabular}{lcccccccccc}
\hline Cultivar & \multicolumn{2}{c}{$\begin{array}{c}\text { Length } \\
(\mathbf{c m})\end{array}$} & \multicolumn{2}{c}{$\begin{array}{c}\text { Number per } \\
\text { Plantlet }\end{array}$} & \multicolumn{2}{c}{$\begin{array}{c}\text { Fresh weight } \\
\text { (g) }\end{array}$} & \multicolumn{3}{c}{$\begin{array}{c}\text { Dry weight } \\
\text { (g) }\end{array}$} \\
& \multicolumn{2}{c}{ Root } & Shoot & Roots & Leaves & Roots & Crown Leaves & Roots & Crown Leaves \\
\hline Festival & 1.19 & 5.35 & 6.46 & 9.53 & 0.29 & 0.022 & 0.30 & 0.041 & 0.004 & 0.02 \\
Sweet Charlie & 3.19 & 8.40 & 12.28 & 12.42 & 0.41 & 0.029 & 0.52 & 0.071 & 0.003 & 0.06 \\
LSD at 0.05 level & 0.41 & 0.6 & 1.81 & 0.95 & 0.08 & NS & 0.16 & 0.01 & NS & 0.04 \\
& & & & & & & & & & \\
\hline
\end{tabular}

NS: Not significant at 0.05 level of probability

Table 2. Effect of two auxins (IBA + NAA) and activated charcoal on the growth measurements of strawberry plantlets cultured in vitro at 6 weeks of culture

\begin{tabular}{|c|c|c|c|c|c|c|c|c|c|c|}
\hline \multirow[t]{2}{*}{$\begin{array}{l}\text { Treatments of auxins and } \\
\text { activated charcoal }\end{array}$} & \multicolumn{2}{|c|}{$\begin{array}{l}\text { Length } \\
\text { (cm) }\end{array}$} & \multicolumn{2}{|c|}{$\begin{array}{c}\text { Number per } \\
\text { plantlet }\end{array}$} & \multicolumn{3}{|c|}{$\begin{array}{c}\text { Fresh weight } \\
\text { (g) }\end{array}$} & \multicolumn{3}{|c|}{$\begin{array}{l}\text { Dry weight } \\
\text { (g) }\end{array}$} \\
\hline & Root & Shoot & Roots & Leaves & Roots & Crown & 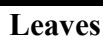 & Roots & Crown & 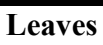 \\
\hline 1/2 MS-medium+ 1.0 mg/l IBA. & 1.92 & 6.54 & 15.08 & 11.83 & 0.16 & 0.03 & 0.05 & 0.02 & 0.003 & 0.05 \\
\hline 1² MS-medium + 1.0 mg/l NAA. & 1.42 & 6.54 & 9.17 & 11.58 & 1.14 & 0.04 & 0.06 & 0.13 & 0.003 & 0.05 \\
\hline $\begin{array}{l}1 / 2 \text { MS-medium + } 0.5 \mathrm{mg} / \mathrm{l} \text { IBA + } \\
0.5 \mathrm{mg} / \mathrm{l} \text { NAA. }\end{array}$ & 2.13 & 7.54 & 12.5 & 11.75 & 1.06 & 0.04 & 0.08 & 0.05 & 0.005 & 0.08 \\
\hline $\begin{array}{l}1 / 2 \text { MS-medium }+1 \mathrm{mg} / \mathrm{l} \mathrm{IBA}+ \\
0.5 \mathrm{~g} / \mathrm{l} \text { activated charcoal. }\end{array}$ & 2.78 & 8.04 & 8.08 & 11.42 & 0.05 & 0.02 & 0.06 & 0.01 & 0.004 & 0.07 \\
\hline $\begin{array}{l}1 / 2 \mathrm{MS}-\text { medium }+1 \mathrm{mg} / \mathrm{l} \text { NAA }+ \\
0.5 \mathrm{~g} / \mathrm{l} \text { activated charcoal. }\end{array}$ & 2.41 & 6.63 & 5.27 & 9.92 & 0.02 & 0.02 & 0.04 & 0.01 & 0.003 & 0.04 \\
\hline $\begin{array}{l}1 / 2 \mathrm{MS}-\text { medium }+0.5 \mathrm{mg} / \mathrm{l} \mathrm{IBA}+ \\
0.5 \mathrm{mg} / \mathrm{l} \mathrm{NAA}+0.5 \mathrm{~g} / \mathrm{l} \text { activated } \\
\text { charcoal. }\end{array}$ & 2.52 & 5.96 & 6.10 & 9.33 & 0.02 & 0.01 & 0.04 & 0.01 & 0.003 & 0.04 \\
\hline LSD at 0.05 level & 0.72 & 1.05 & 3.14 & 1.64 & 0.28 & 0.02 & 0.02 & 0.06 & NS & 0.02 \\
\hline
\end{tabular}

NS: Not significant at 0.05 level probability. 
On the other hand, using $1 / 2$ MS-medium supplemented with $1.0 \mathrm{mg} / \mathrm{l}$ NAA being the most effective treatment and recorded the maximum increase of fresh and dry weight of roots per plantlet. Furthermore, the fresh weight of crown and leaves, as well as the dry weight of leaves per complete plantlet were obtained via using $1 / 2$ MS-medium supplemented with 0.5 $\mathrm{mg} / 1 \mathrm{IBA}+0.5 \mathrm{mg} / 1 \mathrm{NAA}$.

As for the role of auxins such as naphthalene acetic acid (NAA) and indol butyric acid (IBA), Krishnamoorthy (1981) reported that the stimulatory effect of auxins addition to the culture medium, both roots and shoots formation may be attributed to cell division by mitoses which added new cells and cell elongation of already existing cell by enlargement of the vacuole. In addition, Torres (1989) stated that, auxin are required for cell elongation, stimulation of callus induction, cell growth, as well as intiation of shoots and particularly roots.

The obtained results are in harmony with those reported by Moradi et al. (2011) they found that, the highest number for each of roots and root length were obtained from $1 / 2$ MSmedium contained 0.2-0.5 mg/1 IBA. Moreover, Zobayer et al. (2011) revealed that the maximum frequency of rooting and the highest number of roots were obtained on MS-medium contained $1.0 \mathrm{mg} / \mathrm{l}$ IBA. Ashrafuzzaman et al. (2013) found that,application of IBA at a concentration of $0.5 \mathrm{mg} / 1$ to $1 / 2$ MS-medium being the best performance of strawberry roots, as well as the highest number of roots of per culture (6) and the longest root $(3.05 \mathrm{~cm})$, while half strength MS-medium ( $1 / 2$ MS-medium) without IBA did not reflect any significant response on the roots induction. In addition, Bader-Elden (2013) reported that, the shoots were transferred to MS-medium supplemented with five concentrations of both IBA or NAA $(0.0,0.5,1.0$ and 1.5 and $2.0 \mathrm{mg} / \mathrm{l})$ individually, showed that IBA at $0.5 \mathrm{mg} / 1$ proved to be the most suitable treatment for roots indication $(8,4$ roots per shoot and the average root length was $7.21 \mathrm{~cm}$ ). Harugade et al. (2014) concluded that, the different concentration of IBA $(0.1$ and $1.5 \mathrm{mg} / \mathrm{l})$ and $1.0 \mathrm{mg} / 1 \mathrm{IBA}$ being the most superior and suitable treatment for roots induction ( 5 roots per explant, and the average root length was $3.68 \mathrm{~cm}$ ).
Furthermore, Sutter et al. (1997), Bhatt and Dhar (2000), Hemant et al. (2001), Elmana et al. (2003), Kaushal et al. (2006), Sakila et al. (2007), Adak et al. (2009), Sutan et al. (2009), Haddadi and Abd El-Aziz (2010) and Hasan et al. (2010) came to similar findings .

Finally, from the previously mentioned results and discussion, it could be suggested that, the depressive or the stimulating effect on the roots formation was differed greatly according to the type of auxin and its concentration in the cultured medium of rooting stage.

As for the effect of activated charcoal, it is quite clear from Table 2 that, addition of activated charcoal in the rooting medium improved the potenial for adventitious rooting, not only in terms of rooting rates, but also in enhancement of the number and length of the roots, as well as roots score per plantlet. This stimulating effect of activated charcoal on roots ability was particularly associated with mature explants. Activated charcoal may affect the activity and/or stability of plant growth regulators by reducing or excluding light in in vitro culture. In addition, activated charcoal can be attributed to removal the inhibitory substance from the medium, or released by the tissue itself (Fridborg et al., 1978). Moreover, activated charcoal may be able to absorb toxic brown or black pigments (phenol like compounds and melanin), as well as other unknown colourless toxic compounds. Also, the obtained results are in agreement with those reported by LopezAranda et al. (1994) who found that addition of $500 \mathrm{mg} / 1$ activated charcoal, enhanced roots formation of strawberry. Erenoglu et al. (1995) reported that, the highest number of roots per plantlet was obtained with $0.5 \mathrm{~g} / 1$ activated charcoal or $1.0 \mathrm{mg} / 1 \mathrm{IBA}$. Furthermore, Adak et al. (2001) showed that, using activated charcoal was more successful on rooting formation than IBA and NAA. In addition, application of $5.0 \mathrm{~g} / \mathrm{l}$, activated charcoal had more rooting success than application 1.0 and $2.5 \mathrm{~g} / 1$ activated charcoal. Gautam et al. (2001) found that, the highest roots induction frequency $(95.23 \%)$ were obtained with $1 / 4$ MS- mediam $+1.0 \mathrm{mg} / 1$ IBA and charcoal at a rate of $200 \mathrm{mg} / \mathrm{l}$ In addition, Mahajan et al. (2001), Kaur et al. (2005), Kaushal et al. (2006) and Adak and 
Pekmezci (2011) came to similar conclusion. On the other hand, Nower et al. (2011) reported that, MS-medium supplemented with $0.5 \mathrm{mg} / \mathrm{l}$ IBA with activated charcoal being the supperior treatment and recorded the highest increase of number of roots, root length and the fresh weight of plantlet, as compared with the other treatments of unxins (IAA or NAA).

Accordingly, from the above mentioned results and discussion, it may be suggested that, the two factors of study, i.e. auxins (IBA and NAA) and activated charcoal exerted a marked and significant effect on roots formation of strawberry plantlets during rooting stage in vitro.

\section{Effect of the interaction between strawberry cultivars, auxins (IBA and NAA) and activated charcoal}

The presented results in Table 3 and illustrated in Fig. 1 indicated that, the effect of interaction treatments between strawberry cultivars, different concentrations of the two auxins (IBA and NAA) and activated charcoal caused a significant effect on length of both root and shoot, number of roots and leaves, as well as the fresh and dry weight of roots, crown and leaves per plantlet which cultured in vitro during rooting stage. Transfer shoots of Sweet Charlie cultivar to the rooting medium contained of $1 / 2$ MS-medium +1 $\mathrm{mg} / 1 \mathrm{IBA}+0.5 \mathrm{~g} / 1$ activated charcoal recorded the highest value for each of root and shoot length, number of leaves per plantlet, the fresh and the dry weight of leaves, as well as the dry weight of crown. While, the highest number of roots was recorded by culturing shoots of the same cultivar on $1 / 2$ MS-medium supplemented with $1.0 \mathrm{mg} / 1 \mathrm{IBA}$, also cultured shoots of the same cultivar on $1 / 2$ MS-medium $+1.0 \mathrm{mg} / 1$ NAA gave the maximum values of roots dry weight. Moreover, the highest fresh weight of each of roots and crown per plantlet was obtained from cultured shoots of Festival cultivar on $1 / 2$ MS-medium supplemented with $0.5 \mathrm{mg} / 1 \mathrm{IBA}+0.5 \mathrm{mg} / 1 \mathrm{NAA}$ or $1.0 \mathrm{mg} / 1 \mathrm{NAA}$, respectively. On the other hand, the highest increase of crown fresh weight per plantlet was more distinct via the interaction treatment between such cultivar and using $1 / 2$ MS-medium supplemented with $1.0 \mathrm{mg} / \mathrm{l} \mathrm{NAA}$.
Finally, from the previously mentioned results and discussion, it could be concluded that, the depressive or the stimulating effect on the roots formation of strawberry plantlets was differed greatly according to the cultivars, the type of auxin, and its concentration, as well as to the dose of activated charcoal in the culture medium.

\section{Chemical Composition of Plantlets}

\section{Effect of cultivars}

It is quite clear from the illustrated results in Table 4 that, there is no significant differences between the two tested strawberry cultivars on the content of nitrogen, phosphorus, potassium, total carbohydrates and total protein (\%) in strawberry plantlets which cultured in vitro during rooting stage.

\section{Effect of auxins and activated charcoal}

Concerning the effect of two auxins (IBA and NAA) and activated charcoal on the chemical composition of the plantlets, the obtained results in Table 5 show that supplementation of $1 / 2$ MS-medium by different concentrations of two auxins (IBA and NAA) and activated charcoal caused a marked effect on the content of $\mathrm{N}, \mathrm{P}, \mathrm{K}$, total carbohydrates and total protein (\%) of formed plantlets in vitro. In addition, using $1 / 2$ MS-medium supplemented with $0.5 \mathrm{mg} / 1 \mathrm{IBA}+0.5 \mathrm{mg} / \mathrm{l} \mathrm{NNA}+0.5 \mathrm{~g} / 1$ activated charcoal being the superior one and came in the first rank in this respect, followed by using $1 / 2$ MS-medium supplemented with 0.5 $\mathrm{mg} / 1 \mathrm{IBA}+0.5 \mathrm{mg} / \mathrm{l} \mathrm{NNA}$.

\section{Effect of the interaction between cultivars, auxins and activated charcoal}

The presented results in Table 6 show that, $\mathrm{N}, \mathrm{P}, \mathrm{K}$, total carbohydrates and total protein content $(\%)$ in produced strawberry plantlets were significantly affected by the interaction between cultivars and different concentrations of the two auxins (IBA and NAA) and activated charcoal added to the rooting medium of strawberry mass propagation in vitro. Horeover, sub-cultured shoots of Festival cultivar in vitro on rooting medium contained of $1 / 2 \mathrm{MS}$-medium $+0.5 \mathrm{mg} / 1 \mathrm{NAA}+0.5 \mathrm{mg} / 1 \mathrm{IBA}+0.5 \mathrm{gm} / 1$ activated charcoal produced the highest value for each of nitrogen and total protein content $(\%)$ in the formed plantlets. While, sub-cultured 

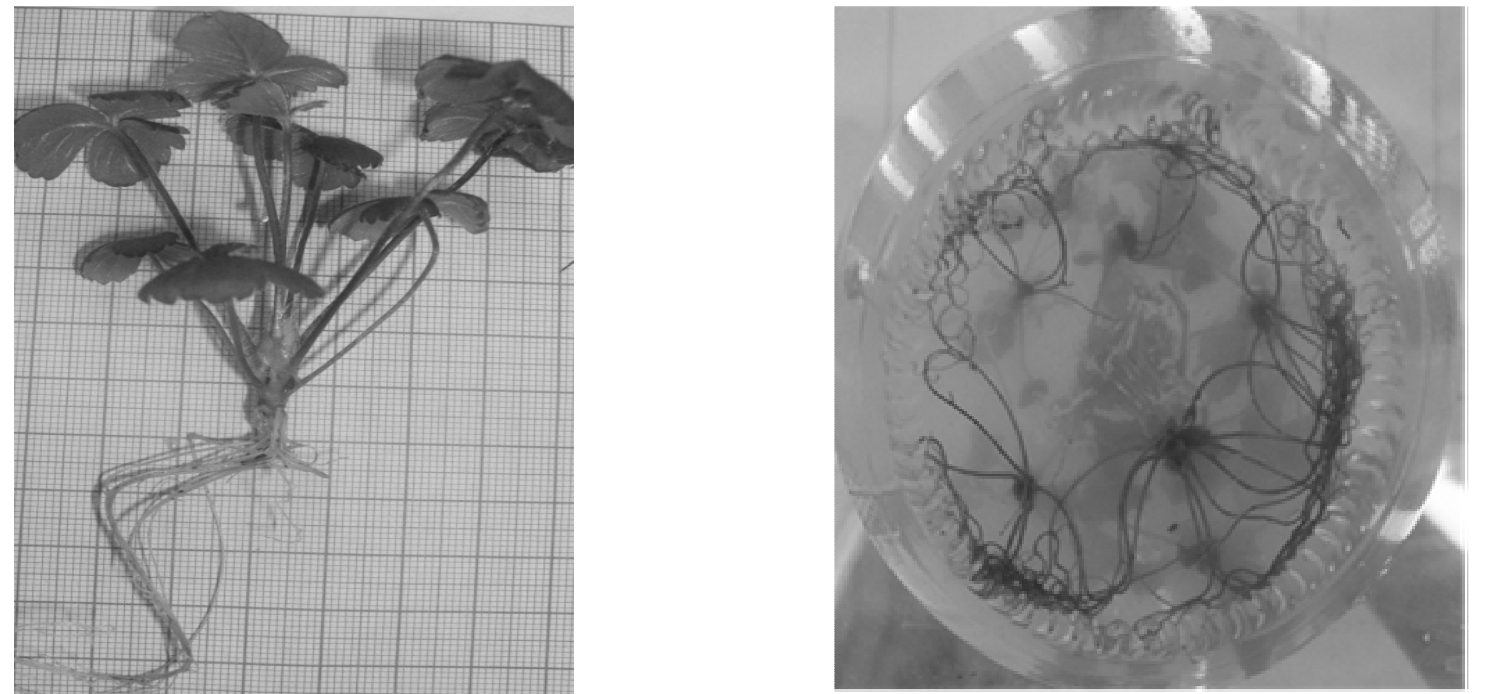

The highest roots number ( $1 / 2$ MS-medium+ $1.0 \mathrm{mg} / 1 \mathrm{IBA})$.

Festival cultivar
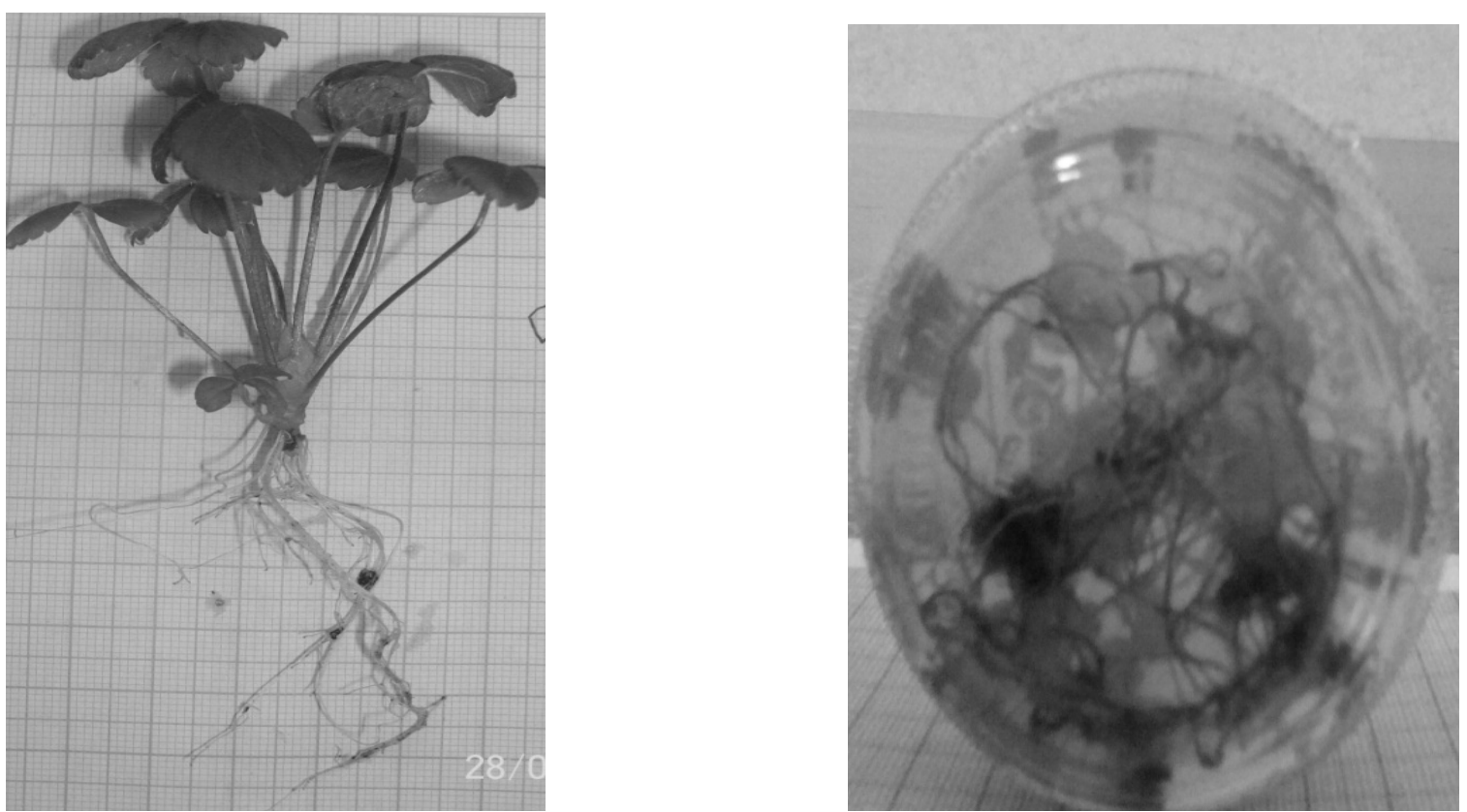

The highest roots number (1/2 MS-medium $+1.0 \mathrm{mg} / 1 \mathrm{IBA})$.

Sweet Charlie cultivar

Fig. 1. Effect of the interaction between strawberry cultivars, auxins (IBA and NAA) and activated charcoal on roots number of strawberry plantlets cultured in vitro during rooting stage 
Table 3. Effect of the interaction treatments between strawberry cultivars, auxins (IBA and NAA) and activated charcoal on the growth measurements of strawberry plantlets cultured in vitro at 6 weeks of culture

\begin{tabular}{|c|c|c|c|c|c|c|c|c|c|c|c|}
\hline \multicolumn{2}{|l|}{ Treatment } & \multirow{2}{*}{\multicolumn{2}{|c|}{$\begin{array}{l}\text { Length } \\
\text { (cm) }\end{array}$}} & \multirow{2}{*}{\multicolumn{2}{|c|}{$\begin{array}{c}\text { Number per } \\
\text { plantlet }\end{array}$}} & \multirow{2}{*}{\multicolumn{3}{|c|}{$\begin{array}{c}\text { Fresh weight } \\
\text { (g) }\end{array}$}} & \multirow{2}{*}{\multicolumn{3}{|c|}{$\begin{array}{l}\text { Dry weight } \\
\text { (g) }\end{array}$}} \\
\hline \multirow[t]{2}{*}{ Cultivar } & \multirow[t]{2}{*}{ Auxins and activated charcoal } & & & & & & & & & & \\
\hline & & Root & Shoot & Roots & Leaves & Roots & Crown & Leaves & Roots & Crown & Leaves \\
\hline \multirow[t]{6}{*}{ Festival } & 1/2 MS-medium + 1.0 mg/l IBA. & 6.000 & 2.0800 & 11.830 & 10.830 & 0.090 & 0.030 & 0.250 & 0.011 & 0.003 & 0.039 \\
\hline & 1/2 MS-medium + 1.0 mg/l NAA. & 6.170 & 1.1700 & 7.670 & 10.500 & 0.050 & 0.046 & 0.460 & 0.047 & 0.004 & 0.057 \\
\hline & $\begin{array}{l}1 / 2 \text { MS-medium + } 0.5 \mathrm{mg} / \mathrm{I} \text { IBA + 0.5 mg/l } \\
\text { NAA. }\end{array}$ & 2.000 & 2.000 & 10.330 & 10.830 & 1.490 & 0.039 & 0.580 & 0.042 & 0.005 & 0.078 \\
\hline & $\begin{array}{l}\text { 1/2 MS-medium + } 1 \mathrm{mg} / \mathrm{l} \text { IBA }+0.5 \mathrm{~g} / \mathrm{l} \\
\text { activated charcoal. }\end{array}$ & 4.420 & 0.390 & 2.330 & 8.000 & 0.012 & 0.004 & 0.097 & 0.003 & 0.002 & 0.022 \\
\hline & $\begin{array}{l}1 / 2 \text { MS-medium + } 1 \text { mg/l NAA + } 0.5 \mathrm{~g} / \mathrm{l} \\
\text { activated charcoal. }\end{array}$ & 4.580 & 0.740 & 2.200 & 8.330 & 0.006 & 0.004 & 0.230 & 0.003 & 0.002 & 0.023 \\
\hline & $\begin{array}{l}1 / 2 \text { MS-medium }+0.5 \mathrm{mg} / \mathrm{l} \mathrm{NAA}+0.5 \mathrm{mg} / \mathrm{l} \\
\mathrm{IBA}+0.5 \mathrm{~g} / \mathrm{l} \text { activated charcoal. }\end{array}$ & 3.580 & 0.780 & 4.370 & 8.670 & 0.013 & 0.008 & 0.117 & 0.005 & 0.003 & 0.025 \\
\hline \multirow{6}{*}{$\begin{array}{l}\text { Sweet } \\
\text { Charlie }\end{array}$} & 1/2 MS-medium + 1.0 mg/l IBA. & 7.080 & 1.750 & 18.330 & 12.830 & 0.230 & 0.026 & 0.410 & 0.028 & 0.003 & 0.061 \\
\hline & 1/2 MS-medium + 1.0 mg/l NAA. & 6.920 & 1.670 & 10.670 & 12.670 & 0.770 & 0.028 & 0.440 & 0.216 & 0.003 & 0.071 \\
\hline & $\begin{array}{l}1 / 2 \text { MS-medium + } 0.5 \mathrm{mg} / \mathrm{l} \text { IBA + } 0.5 \mathrm{mg} / \mathrm{l} \\
\text { NAA. }\end{array}$ & 7.330 & 2.250 & 14.670 & 12.670 & 0.630 & 0.039 & 0.427 & 0.062 & 0.005 & 0.073 \\
\hline & $\begin{array}{l}\text { 1/2 MS-medium }+1 \mathrm{mg} / \mathrm{l} \text { IBA }+0.5 \mathrm{~g} / \mathrm{l} \\
\text { activated charcoal. }\end{array}$ & 11.670 & 5.170 & 13.830 & 14.830 & 0.090 & 0.035 & 0.672 & 0.016 & 0.006 & 0.115 \\
\hline & $\begin{array}{l}\text { 1/2 MS-medium }+1 \mathrm{mg} / \mathrm{l} \text { NAA }+0.5 \mathrm{~g} / \mathrm{l} \\
\text { activated charcoal. }\end{array}$ & 8.670 & 4.080 & 8.330 & 11.500 & 0.042 & 0.026 & 0.300 & 0.007 & 0.004 & 0.054 \\
\hline & $\begin{array}{l}1 / 2 \mathrm{MS}-\text { medium }+0.5 \mathrm{mg} / \mathrm{l} \mathrm{NAA}+0.5 \mathrm{mg} / \mathrm{l} \\
\text { IBA }+0.5 \mathrm{~g} / \mathrm{l} \text { activated charcoal. }\end{array}$ & 8.330 & 4.250 & 7.830 & 10.000 & 0.032 & 0.021 & 0.232 & 0.006 & 0.004 & 0.054 \\
\hline \multicolumn{2}{|c|}{ LSD at 0.05 level } & 1.49 & 1.01 & 4.44 & 2.32 & 0.402 & 0.025 & 0.194 & 0.088 & 0.002 & 0.026 \\
\hline
\end{tabular}

Table 4. Effect of cultivars on the chemical composition of strawberry plantlets cultured in vitro at 6 weeks of culture

\begin{tabular}{lccccc}
\hline Cultivar & \multicolumn{5}{c}{ Chemical composition of plantlets (\%) } \\
\cline { 2 - 6 } & $\mathbf{N}$ & $\mathbf{P}$ & K & Total carbohydrates Total protein \\
\hline Festival & 0.41 & 0.13 & 0.63 & 17.36 & 2.55 \\
Sweet Charlie & 0.42 & 0.14 & 0.64 & 17.35 & 2.59 \\
LSD at 0.05 level & NS & NS & NS & NS & NS \\
\hline
\end{tabular}

NS: Not significant at 0.05 level of probability. 
Table 5. Effect of auxins (IBA and NAA) and activated charcoal on the chemical composition of strawberry plantlets cultured in vitro at 6 weeks of culture

\begin{tabular}{|c|c|c|c|c|c|}
\hline \multirow[t]{2}{*}{ Treatments of auxins and activated charcoal } & \multicolumn{5}{|c|}{ Chemical composition of plantlets (\%) } \\
\hline & $\mathbf{N}$ & $\mathbf{P}$ & $\mathbf{K}$ & $\begin{array}{c}\text { Total } \\
\text { carbohydrates }\end{array}$ & $\begin{array}{c}\text { Total } \\
\text { protein }\end{array}$ \\
\hline $1 / 2$ MS-medium + 1.0 mg/l IBA. & 0.39 & 0.12 & 0.59 & 17.17 & 2.44 \\
\hline $1 / 2$ MS-medium + 1.0 mg/l NAA. & 0.37 & 0.11 & 0.59 & 16.54 & 2.32 \\
\hline 1/2 MS-medium + 0.5 mg/l IBA + 0.5 mg/l NAA. & 0.43 & 0.15 & 0.66 & 17.74 & 2.71 \\
\hline $\begin{array}{l}1 / 2 \text { MS-medium + } 1 \mathrm{mg} / \mathrm{l} \mathrm{IBA}+0.5 \mathrm{~g} / \mathrm{l} \text { activated } \\
\text { charcoal. }\end{array}$ & 0.42 & 0.14 & 0.63 & 17.47 & 2.62 \\
\hline $\begin{array}{l}1 / 2 \text { MS-medium }+1 \mathrm{mg} / \mathrm{l} \text { NAA }+0.5 \mathrm{~g} / \mathrm{l} \text { activated } \\
\text { charcoal. }\end{array}$ & 0.41 & 0.13 & 0.62 & 17.32 & 2.56 \\
\hline $\begin{array}{l}1 / 2 \mathrm{MS}-\text { medium }+0.5 \mathrm{mg} / \mathrm{l} \mathrm{IBA}+0.5 \mathrm{mg} / \mathrm{l} \mathrm{NAA}+ \\
0.5 \mathrm{~g} / \mathrm{l} \text { activated charcoal. }\end{array}$ & 0.45 & 0.16 & 0.69 & 17.89 & 2.78 \\
\hline LSD at 0.05 level & 0.02 & 0.01 & 0.01 & 0.45 & 0.11 \\
\hline
\end{tabular}

Table 6. Effect of the interaction between cultivars, auxins (IBA and NAA) and activated charcoal on the chemical composition of strawberry plantlets which cultured in vitro at 6 weeks of culture

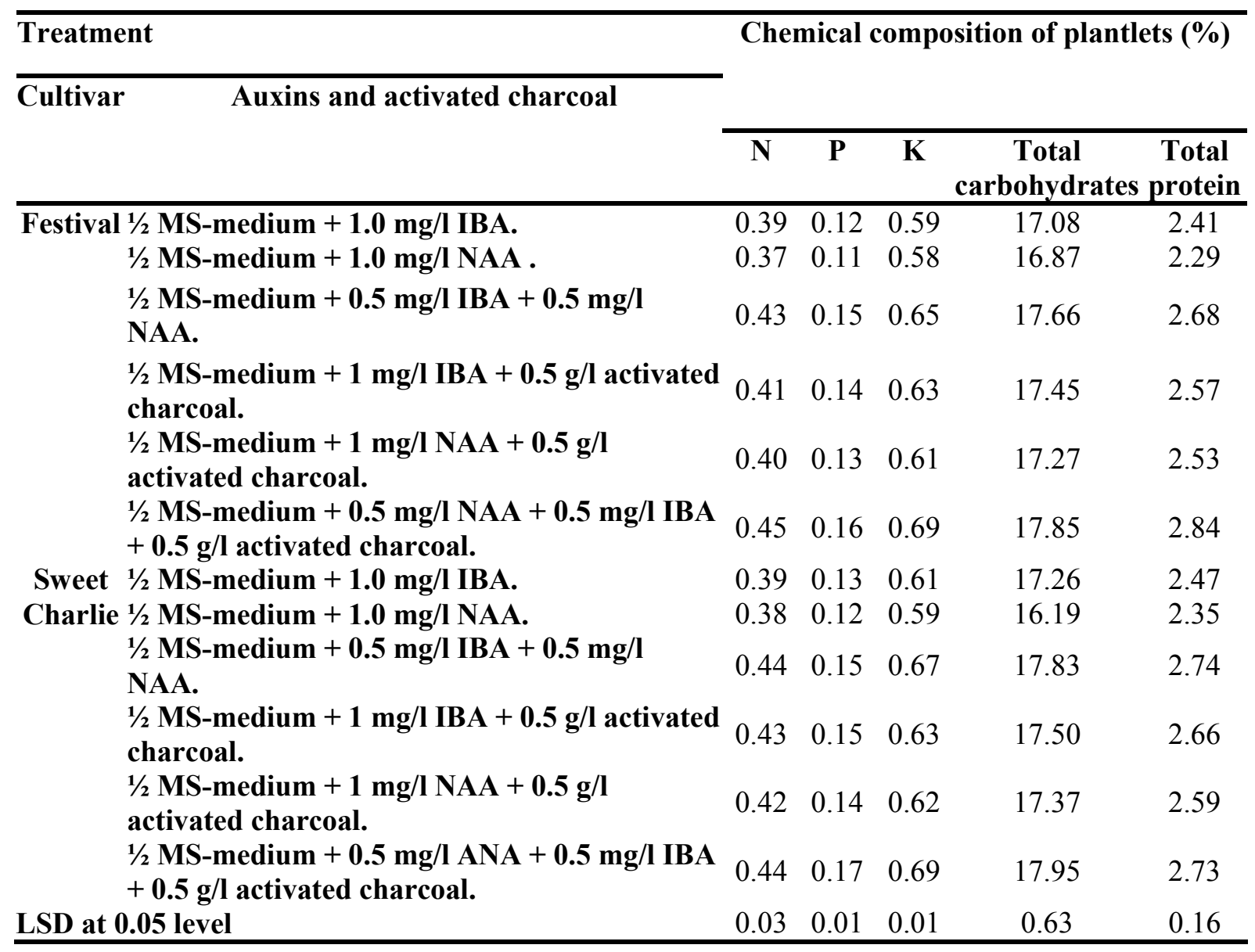


shoots of Sweet Charlie cultivar on the same rooting medium recorded the highest value for each of phosphorus, potassium and total carbohydrates content (\%) of the plantlet cultured in vitro.

On the other hand, there is no significant differences of potassium content (\%) between the plantlets of the two tested cultivars under the same rooting medium $1 / 2 \mathrm{MS}$-medium $+0.5 \mathrm{mg} / 1$ $\mathrm{NAA}+0.5 \mathrm{mg} / \mathrm{l} \mathrm{IBA}+0.5 \mathrm{gm} / \mathrm{l}$ activated charcoal.

Finally, from the previously mentioned results, it could be suggested that, the depressive or the stimulative effect on the chemical composition of strawberry plantlets cultured in vitro during rooting stage were differed significantly according to the cultivars, the type of auxin and its concentration, as well as the dose of activated charcoal in culture medium.

\section{REFERENCES}

Adak, N. and M. Pekmezci (2011). The effect of different auxin types and active charcoal levels on plant growth and development at the acclimization stage in different strawberry cultivars. Anadolu Tarm Bilimleri Dergisi, 26 (2): 91-100.

Adak, N., M. Pekmezci and H. Gubbuk (2001). Investigations on propagation of different strawberry cultivars by meristem culture. Ziraat Fakultesi Dergisi, Akdeniz Univ., 14 (1): 119-126.

Adak, N., L. Kaynak, M. Pekmezci and H. Gubbuk (2009). The effect of various hormone types on in vitro propagation of strawberry. Acta Hort., 829: 305-308.

Ara, T., M.R. Karim, M.A. Aziz, R. Karim, R. Islam and M. Hossain (2013). Micropropagation and field evaluation of seven strawberry genotypes suitable for agroclimatic condition of Bangladesh. Afr. J. Agric. Res., 8:1194-1199.

Ashrafuzzaman, M., S.M. Faisal, D. Yadav, D. Khanam and F. Raihan (2013). Micropropagation of strawberry (Fragaria $X$ ananassa Duch) through runners. Bangladesh J. Agric Res., 38 (3): 467 - 472.
Badr-Elden, A.M (2013). An effective protocol for in vitro storage and ex vitro re-growth of strawberry capsules. Atlas J. Chem. and Biochem., 1: $30-38$.

Bhatt, I.D. and U. Dhar (2000). Micropropagation of Indian wild strawberry. Plant Cell, Tissue and Organ Culture, 60:83 - 88.

Bremner, J.M. and C.S. Mulvaney (1982). Total nitrogen. In: Page, A.L.; R.H. Miller and D.R. Keeney (Ed.). Methods of Soil Analysis. Part 2, Ame. Soc. Agron. Madison. WI. USA, $595-624$.

Dogras, C., A.S. Iomos and C.P. Asomakelis. (1991). Suger and dry matter changes in potatos stored in clamp in mountainous region of northern Dreece. Potato Res., 34: 211-214.

Elmana, H.E.M., A.A. El Hassan and M.M.A. Elballa (2003). In vitro propagation of strawberry (Fragaria $X$ ananassa Duch) using shoot tip explants. UKJ. Agric. Sci., 11 (3): 349 - 358 .

Erenoglu, B., M. Burak and G. Gorur (1995). Study on the effects of etiolation, IBA concentration and activated charcoal on the rooting of micropropagated Aliso and Tioga strawberry plants. Bahce, 24: 1/2, 3-12.

FAO (2014). Searchable on line statistical database from Food and Agriculture Division of the United Nations http://www.fao.org.

Fridborg, G.; M. Pedersen; L. Landstrom, and T. Eriksson (1978). The effect of activated charcoal on tissue cultures: adsorption of metabolites inhibiting morphogenesis. Physiol . Plant., 43: 104 - 106.

Gautam, H., R. Kaur, D.R. Shama and T. Neetu (2001). A comparative study on in vitro and ex vitro rooting of micropropagated shoots of strawberry (Fragaria X ananassa Duch.). Plant Cell Biotech. and Molec. Biol., 2: 149152.

Giampieri, F., J.M. Alvarez-Suarez and M. Battino (2015). Strawberry and human health: Effects beyond antioxidant activity. J. Agric. and Food Chemis., 62: 3867-3876. 
Haddadi, F. and M. Abd El-Aziz (2010). Micropropagation of strawberry cv. Camarosa: Prolific shoot regeneration from in vitro shoot tips using Thidiazuron with N6-benzylamino- purine. Hort. Sci., 45: 453 $-456$.

Harugade, S., R.H. Tabe and S. Chaphalkar. (2014). Micropropagation of Strawberry (Fragaria $X$ ananassa Duch.). Int. J. Curr. Microbiol. Appl. Sci., 3: 344 - 347.

Hasan, M.N., S. Nigar, M.A.K. Rabbi, S.B. Mizan and M.S. Rahman (2010). Micropropagation of Strawberry (Fragaria X ananassa Duch.). Int. J. Sustain. Crop Prod., 5 (4): 36-41.

Hemant, G., R. Kaur, D.R. Sharma, T. Neetu, H. Gautam and N. Thakur (2001). Acomparative study on in vitro and ex vitro rooting of micropropagated shoots of strawberry (Fragaria $X$ ananassa Duch.). Plant Cell Biotech. and Molecular Biol., 2 : 149 - 152.

Jackson, M.L. (1970). Soil Chemical Analysis. Prentice Hall. Englewood Gliffs, N.J.

James, C.S. (1995): Analytical Chemistry of Foods. Blokie Acad. And Professional, London, England.

Kaur, R., H. Gautam and D.R. Sharma (2005). A low cost strategy for micropropagation of strawberry (Fragaria X ananassa Duch.) cv. Chandler. Acta Hort., 696:129-133.

Kaushal, K., A.K. Nath and D.R. Sharma (2006). Establishment of callus cultures and plant regeneration in strawberry (Fragaria $X$ ananassa Duch.) cv. Chandler. Indian J. Plant Physiol., 11 (2): 136-144.

Krishnamoorthy, H.N. (1981). Plant Growth Substances. TATA. Mc Graw-Hill Pub. Comp. Limt., New York (USA), New Delhi, (India).

Lopez-Aranda, J.M., F. Pliego-Alfaro, I. LopezNavidad and M. Barcelo-Munoz (1994). Micropropagation of strawberry (Fragaria X ananassa Duch.). Effect of mineral salts, benzyladenine levels and number of subcultures on the in vitro and field behaviour of the obtained microplants and the fruiting capacity of their progeny. J. Hort. Sci., 69 (4): 625-637.
Mahajan, R., R. Kaur, A. Sharma and D.R. Sharma (2001). Micropropagation of strawberry cultivars Chandler and Fern. Crop Improve., 28 ( 1): 19-25.

Mohamed, A.E. (2007). Somaclonal variation in micropropagated strawberry detected at the molecular level. Int. J. Agric. Biol., 9 (5): 721-725.

Moradi, K., M. Otroshy and M.R. Azimi (2011). Micropropagation of strawberry by multiple shoots regeneration tissue cultures. J. Agric. Tech., 7: 1755 - 1763.

Murashige, T. and F. Skoog (1962). Arevised medium for rapid growth and bioassays with tobacco tissue culture. Physiol. Plant. 15: 473 $-497$.

Murti, R.H. and Y.R. Yeoung (2013). Effects of BA and IBA concentrations and subculture frequent on meristem culture of strawberry. ARPN J. Agric. and Biol. Sci., 8(5): 405 410.

Nower, A.A., A.I. Ibrahim, H.A. Emara, S.Y. Mohamed and M.S. Atfi (2011). Preliminary study on propagation and genetic stability of strawberry (Fragaria X ananassa Duch.) in vitro. Proced. $3^{\text {rd }}$ Int. Conf. Genet. Eng. and its Appl., 203- 225.

Olsen, S.R. and L.E. Sommers (1982). Phosphorus. In: AL; R.H. Miller and D.R. Keeney (Ed.). Methods of Soil Analysis. Part 2, Ame. Soc. Agron. Madison, WI. USA, 403 -340 .

Pregle, E. (1945). Quantitative organic microanalysis. $4^{\text {th }}$ Ed., J. Chundri, London, 385 387.

Sakila, S., M.B. Ahmed, U.K. Roy, M.K. Biswas, R. Karim, M.A. Razvy, M. Hossain, R. Islam and A. Hoque (2007). Micropropagation of Strawberry (Fragaria X ananassa Duch.). A Newly Introduced Crop in Bangladesh. Ame.-Euras. J. Sci. Res., 2 (2): 151-154.

Snedecor, G.W. and W.G Cochran (1980). Statistical Methods, $7^{\text {th }}$ Ed., Iowa State Univ. Press, Iowa, USA.

Suţan, A.N., A. Popescu and V. Isac (2009). The effects of culture medium composition on in vitro rooting of two intergeneric hybrids 
fragaria $X$ potentilla. Analele Universitatii din Oradea, Fascicula Biol., 16: 150 -154.

Sutter, E.G., H. Ahmadi, J.M. Labavitch, A. Altman and M. Ziv (1997). Direct regeneretion of strawberry (Fragaria $X$ ananassa Duch.) from leaf disks. Acta. Hort., 447: 243-245.
Torres, K.C. (1989). Tissue Culture Techniques for Horticultural Crops. An AVI Book, New York (USA).

Zobayer, N.; S.H. Prodhan; S.U. Sikdar; F. Azim and M. Ashrafuzzaman (2011). Study of shoot multiplication of strawberry (Fragaria X ananassa Duch.). int. J. Agric. Res. Innov. and Tech., 1 (1-2) : 69 - 72.

\section{تأثير أصناف الفراولة، والأوكسينات، والفحم النباتي النشط على تكوين الجذور لنبيتات الفراولة معمليا

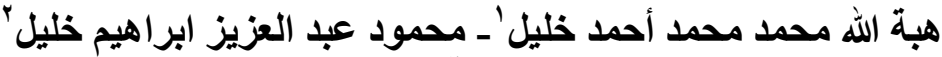

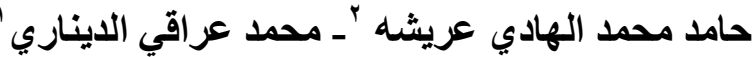

اـ قسم بحوث البطاطس ومحاصيل الخضر خضرية التكاثر ـ معهد بحوث البساتينـ مركز البحوث الزر اعيةـ الجيزهـ مصر

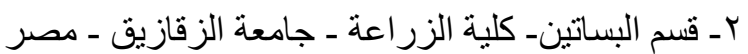

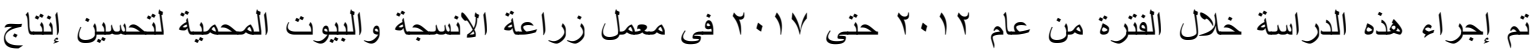

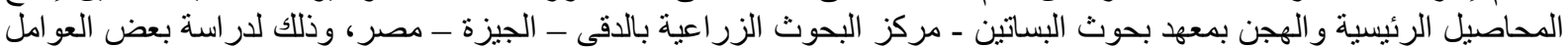

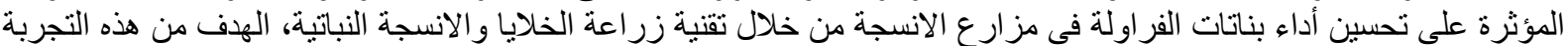

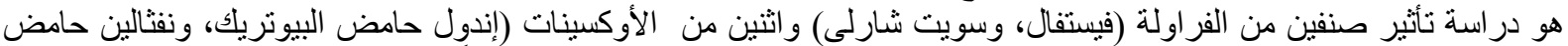

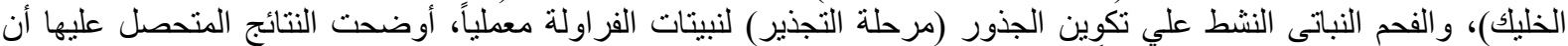

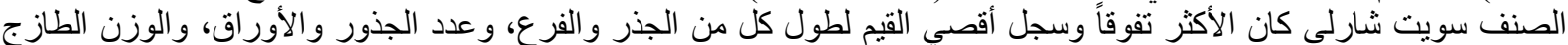

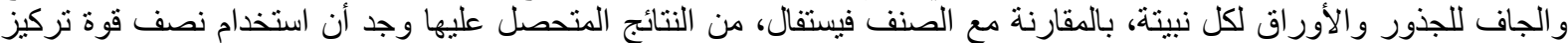

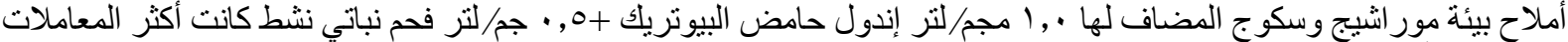

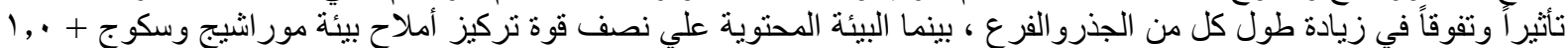

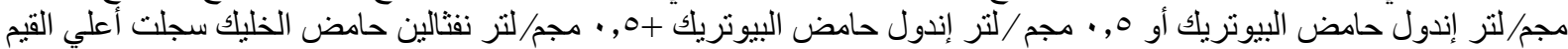

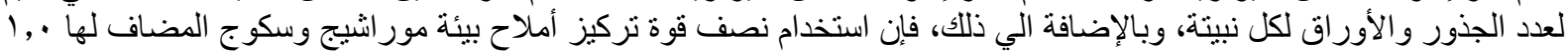

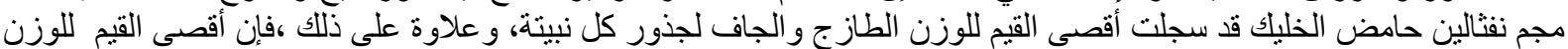

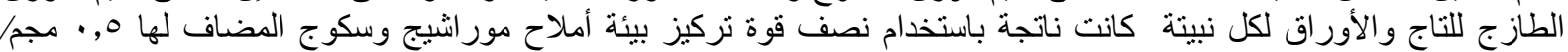

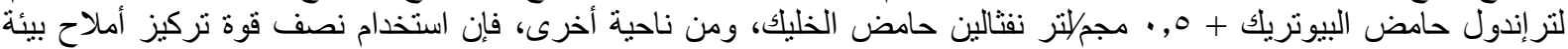

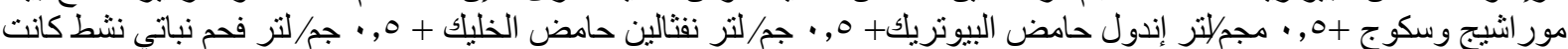

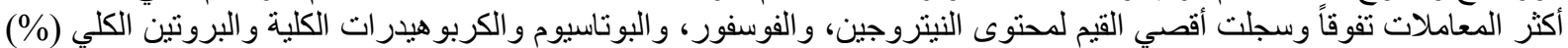

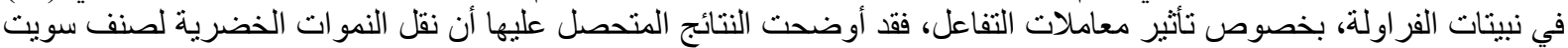

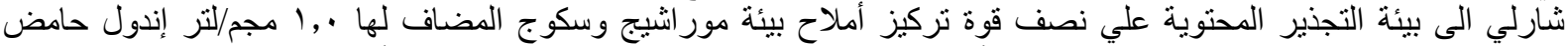

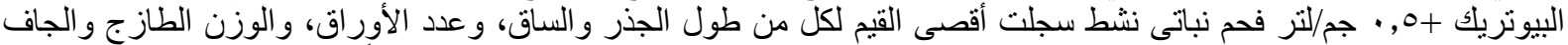

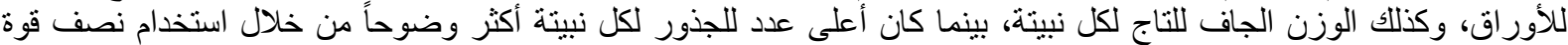

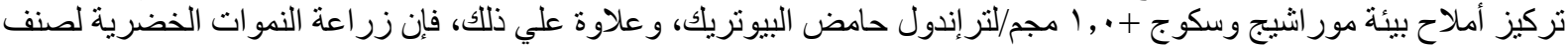

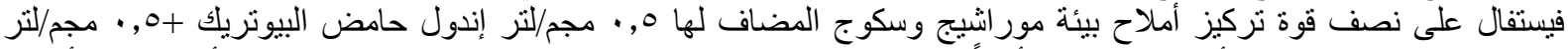

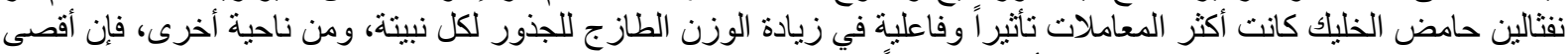

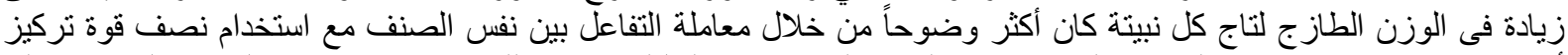

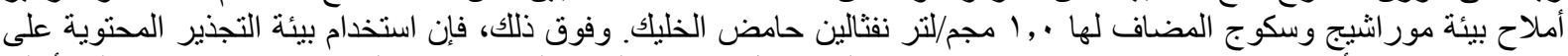

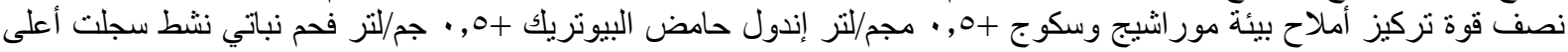

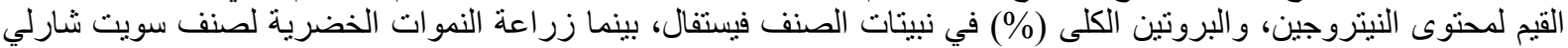

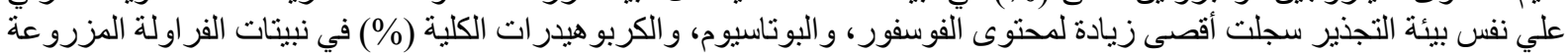

